\title{
Applied linguistics as epistemic assemblage
}

\author{
Alastair Pennycook \\ University of Technology Sydney
}

Any discussion of transdisciplinary applied linguistics needs to engage with three central questions. First, while interdisciplinarity may allow for disciplines to stay in place and engage with each other, transdisciplinarity implies a space beyond or above disciplines. As a result, we have to consider whether applied linguistics is seen as a discipline (in which case it is not transdisciplinary) or whether it is seen as a transdisciplinary field of study (in which case it is not a discipline). Second, while applied linguists may engage with work from other fields - sociology, geography, philosophy, cognitive science are common examples - this does not necessarily mean that we engage with those fields as disciplines. Rather, the engagement with such work is often on the basis that relevant thinkers are engaging themselves with broader epistemic shifts. Such work may therefore be seen as having to do with epistemes rather than disciplines. Third, a focus on transdisciplinarity obscures broader concerns about unequal relations of knowledge production, particularly between North and South. If applied linguistics is to become a responsible field of work, it needs to engage with southern epistemologies. In order to do so, applied linguistic practices can be more usefully understood as temporary assemblages of thought and action that come together at particular moments when language-related concerns need to be addressed. This flexible account helps us see how applied linguistic practices are assemblages of different language-oriented projects, epistemes and matters of concern.

Keywords: assemblage, episteme, southern theory, posthumanism, the commons

\section{Introduction}

A transdisciplinary focus in applied linguistics is certainly to be welcomed over the implausible disciplinary claims that have hampered this field of work through much of its history. Applied linguistics has been subjected to handbooks, introductory texts, conferences and symposia, all trying hard to make the case for 
disciplinary cohesion. Like language standardization, while there may be gains to be made by such processes or normalization, this history of consolidation and exclusion has also rendered applied linguistics unhelpfully narrow in its epistemologies, politics and methods. There are a number of reasons to reject claims to disciplinary status for applied linguistics, including a more persuasive argument that a field of applied study is ordered not so much by a core disciplinary focus but rather by the questions it asks and the fields it engages with - language policy, language in the professions, language in education, and so on - and that the understandings of language, the matters of concern, and the research tools to engage with them change accordingly.

A focus on transdisciplinary applied linguistics, however, is not necessarily the answer to trying to understand the knowledge and politics of applied linguistics. While preferable to both disciplinary and interdisciplinary frameworks (both of which reinforce disciplinary boundaries), a transdisciplinary focus draws attention away not only from the important focus on practice, but also from broader ways in which knowledge is produced, regulated and maintained. A transdisciplinary focus may in fact work against a more flexible notion of academic endeavour. In the next section, I shall explore in greater depth the struggles over disciplinarity in applied linguistics, making a case on several grounds to reject claims that applied linguistics is a discipline. Following this, I will look at the implications of engagement with posthumanist theory, arguing that this is a question of epistemes rather than disciplines. This will be followed by a discussion of Southern theory, and the concern that applied linguistics has a long way to go before it becomes a more responsive and responsible domain of academic work. The conclusion points to ways in which an understanding of applied linguistics as an epistemic assemblage may offer a range of possibilities for renewal.

\section{Applied linguistics as an unlikely discipline}

Applied linguistics can be variously (though not exhaustively) seen as an academic discipline itself (with the various tribal allegiances such a position entails; Becher, 1989); as a profession devoted to the application of another discipline (linguistics) (with the necessary loss of academic prestige such a definition implies); as a field of practice informed by real world language problems (with a view that applied linguists are "practical people working as a community, and it is their modes of practice and communicating with one another, as much as anything, which define them as a professional group", McCarthy, 2001, p. 118); as a theory of the practice (with a view that applied linguistics is "the practice of language study itself, and the theory that could be drawn from that practice" Kramsch, 2015, p. 455); as 
an "interdisciplinary area of inquiry" where research on language-related issues meets wider public concerns (Rampton, 1997, p. 11) (with the worry that it may remain dependent on theories always from elsewhere); or a transdisciplinary domain drawing on different areas to address a range of concerns (with the claim that the field is neither a discipline, nor dependent on other disciplines, but operates independently in relation to language concerns). These different accounts of the field overlap in various ways, and there is insufficient space here to address them all. I shall, therefore, focus particularly on claims to disciplinarity.

If we want to argue for a notion of transdisciplinarity, we need to reconcile the tension between the conception of applied linguistics as a discipline and as a transdisciplinary domain. The point of the 'trans' rather than 'inter' terminology is that it supersedes the initial framework. Translanguaging, for example, is explained as "an approach to the use of language, bilingualism and the education of bilinguals that considers the language practices of bilinguals not as two autonomous language systems as has been traditionally the case, but as one linguistic repertoire with features that have been societally constructed as belonging to two separate languages" (García and Li Wei, 2014, p. 2). That is to say, translanguaging challenges the notion of separable languages that underpin notions such as bilingualism, and posits a different way of thinking about linguistic resources and repertoires.

Likewise, transcultural communication, unlike intercultural communication, does not keep preexisting cultures in place while suggesting that people of different cultural backgrounds can communicate across these cultural divides, but rather suggests a transcultural space that undermines cultural fixity (Pennycook, 2007). It follows, therefore, that if applied linguistics is a transdisciplinary field, then it is no longer a discipline. If it is a discipline that draws on other disciplines, then it is not transdisciplinary. It is important, therefore, to explore first whether a convincing case can be made for applied linguistics as a discipline: If a convincing case can be made, then the argument for transdisciplinarity is foreclosed; if the argument is less convincing, then transdisciplinarity is still an option.

It is certainly the case that a lot of work has been done to consolidate applied linguistics as a discipline. Handbooks, conferences, symposia on applied linguistics (discussions comparing applied linguistics, linguistics applied or appliable linguistics, for example), all perhaps suggest a field desperately trying to convince itself and others of its disciplinary status. One of the most revealing processes of disciplinary gatekeeping can be seen in the way that various handbooks and introductory texts have discussed the place of critical applied linguistics as part of the discipline. In a section of Kaplan's (2002) preface to the The Oxford handbook of applied linguistics, he explains that: 
The editorial group spent quite a bit of time debating whether critical (applied) linguistics/critical pedagogy/critical discourse analysis should be included; on the grounds that critical applied linguistics rejects all theories of language, expresses "skepticism towards all metanarratives" (Lyotard, 1984) and rejects traditional applied linguistics as an enterprise because it has allegedly never been neutral and has, rather, been hegemonic (Rampton, 1997), the editorial group decided not to include the cluster of "critical" activities.

(Kaplan, 2002, p. v-vi)

The second edition in 2010 maintains this same position with more or less the same text aside from a slight lessening of apparent editorial board intentionality (no longer "the editorial group decided" but now "it was the decision of the editorial group"). This is quite a remarkable statement of exclusion. Work that aims to connect applied linguistics to broader social formations - critical discourse analysis, critical literacy, critical approaches to language policy and so on - is excluded on three very doubtful criteria. First is the bizarre claim that critical applied linguistics rejects all theories of language. Critical approaches to applied linguistics of course operate with theories of language, though they have been appropriately sceptical particularly of normative theories derived from linguistics. A scepticism towards grand narratives, meanwhile, is surely a useful intellectual tool, particularly when trying to deal with minority concerns and questions around the politics of difference (Pennycook, 2001). It is also, it should be noted, only applicable to some critical approaches: more traditional Marxist-based work has been quite happy to maintain a grounding in grand narratives. Finally, the concern about neutrality misses the point that such a field of practice requires applied linguists to take a stance. There is no point in working on minority language education, for example, without an element of advocacy.

There is a sense here, however, that this is not really the point, that these grounds for rejection are on the one hand a smoke screen to conceal the broader disquiet with a critical political stance. Certainly, there has always been a level of discomfort in mainstream liberal applied linguistics with the political standpoint of various forms of critical work. The overt political stance on issues of inequality, racism, sexism or homophobia, from some perspectives, unacceptably "prejudges outcomes" (Davies, 2005, p. 32). As Widdowson (2001) argues, by taking an $a$ priori critical stance (rather than maintaining a critical distance - to use a different sense of the critical), critical applied linguistics may impose its own views on the objects of inquiry, taking inappropriate stances on the social world that may be hypocritical because of the impossibility of choosing between different ethical and political concerns. This ineffectual liberal argument is itself at best hypocritical for a domain such as applied linguistics which surely has to take a position on matters of concern, as Latour (2004) calls them. 
While it is tempting to read the dismissal of critical applied linguistics in these terms, these arguments also suggest, on the other hand, a different level of disquiet, a worry about the threat to the security of the discipline rather than a concern over political stances. Liberal applied linguistics is better able to accommodate the political stance of critical applied linguistics (even if it finds it uncomfortable) than the epistemological challenges it perceives to its disciplinary security. This is evident in Davies' (1999, p. 145) An introduction to applied linguistics where he warns of the threat of critical applied linguistics as "a judgemental approach by some applied linguists to 'normal' applied linguistics on the grounds that it is not concerned with the transformation of society." A defence of 'normal' applied linguistics on the grounds that a lot of work was done to establish its disciplinary coherence overlooks the particular inclusionary and exclusionary interests of such disciplinarity (particularly as embedded in conservative institutions of the West/ North). Above all, however, it is not this supposedly judgemental attitude or this will to change society that is at stake here but rather the threat to 'normal' applied linguistics and the ways in which critical applied linguistics is "dismissive totally of the attempt since the 1950s to develop a coherent applied linguistics" (Davies, 1999, p. 141).

The opposition to critical work that has been a feature of such handbooks and introductions has been based more on a concern that some approaches to critical applied linguistics undermine applied linguistics as a discipline than because of its political focus. A liberal applied linguistics can always allow in a critical perspective but it cannot allow its disciplinary backbone to be broken. Critical applied linguistic work that aimed not only at adding a political dimension to standard applied linguistic work (discourse analysis with a critical edge, for example) but also at challenging the epistemological assumptions behind ideas such as language has always been a more challenging proposition to the guardians of the discipline. This is why projects such as Thurlow's (2016) queering of discourse studies matters far more than yet another critical discourse analysis of political rhetoric that may help us see how political discourse works but does nothing to undermine the central assumptions about language and politics that need deeper investigation.

Not only do critical discourse studies, as Van Leeuwen (2018) notes, need to go beyond revealing what texts omit or misrepresent of social reality in order to engage with their moral implications, but it requires "a more committed decentering of language than even multimodal analysts have been able to manage." (Thurlow, 2016, p. 503). This does not therefore merely add a political dimension to discourse studies but rather poses serious epistemological questions about language and discourse. It is these questions that threaten both normative discourse analysis and normative critical discourse studies, since it undermines the epistemological assumptions that sustain the disciplinary claims. It is not the critical political 
stance of critical applied linguistics that threatens the disciplinary guardians but the challenges to the underlying frameworks.

But how well do the claims to disciplinarity that is being so assiduously guarded stack up? There are several reasons to oppose or reject the idea of applied linguistics as a discipline. The first set of arguments have to do with the difficulties of making the case for coherence in a field so oriented towards practice. That applied linguistics has a "lack of unitary theory and of clear disciplinary boundaries" might be seen as a form of disciplinary strength, with "its very openness to outside influences being its strongest and most enduring quality" (McCarthy, 2001, p. 21). Handbooks - collections of disparate articles - have often been more successful than either their contentious introductions (Kaplan, 2002) or books that have aimed to provide an introduction to the field (Davies, 1999; McCarthy, 2001; de Bot, 2015) - a "fool's errand" in McCarthy's (2001, p. 142) words - which have often disappeared quite quickly under a barrage of indifference or critique for their particularity, narrowness, and contentious frameworks. Amongst various limitations of this disciplinary drive, McCarthy suggests a tendency to promote conformity and overlook political and ethical concerns, a disregard for peers from other parts of the world, an inflated sense of importance and a lack of self-criticality (2001, p. 142). Such disciplinary downsides would seem to outweigh the upsides.

The second set of arguments have to do with the politics of knowledge and the concern that disciplines are hegemonic knowledge structures. For Bernstein (2000) the ways knowledge is classified - strong classification in the case of singular forms of knowledge as expressed in disciplines, weaker classification in regions of knowledge as expressed in more practice-oriented domains - are expressions of power. Not only do disciplines have organisational forms, internal hierarchies and differential relations of power that confer advantages to some and disadvantage to others (Trowler, Sanders and Bamber, 2012; Trowler, 2014) but they play a significant role in the regulation of access to knowledge (Bernstein, 2000). Bernstein's concern was with the social implications of the organization of hierarchical knowledge in disciplines though processes of classification (the boundary-making around knowledge) and framing (processes of pedagogical control and dissemination). As May (2014, p. 15) suggests, this helps us to see how and why disciplines "are so often defined (and confined) by a narrowly derived set of research assumptions, approaches, and related models of teaching and learning."

While challenges to applied linguistics as a discipline may bring a downside of insecurity, instability and incoherence, they also bring many benefits of flexibility, innovation and breadth. And from a critical perspective, disciplinary claims to hegemonic knowledge structures have to be challenged, not so much by bringing political concerns to the table but rather in terms of critique of the founding epistemological myths. So, if the very struggles to discipline applied linguistics 
suggest a field desperately trying to make itself into what it is not, the possibility of applied linguistics as a transdisciplinary domain rather than a discipline become more possible to entertain. In the rest of this paper, however, I want to argue why we should be sceptical of talk of transdisciplinarity. It obscures two other crucial sets of knowledge formation: On the one hand, by focusing on the micro-politics and micro-techniques of disciplines, we fail to engage with broader epistemological shifts - sometimes, though not unproblematically, known as turns - that reconfigure the disciplinary terrain. This is a question of epistemes rather than disciplines. This I shall illustrate through a brief discussion of posthumanism and what such an engagement entails. On the other hand, transdisciplinary talk fails to engage with the politics of North-South intellectual formation, or the inequitable structures of global knowledge production. In order to become a politically and ethically responsible field of work, applied linguistics needs to broaden its epistemological repertoires to embrace alternative ways of thinking that it has for too long ignored or dismissed.

\section{Turns, disciplines and epistemes}

Applied linguistics has never been particularly responsive to the various 'turns' that regularly sweep the social sciences. On the one hand this may suggest a field of work rather deaf to the epistemological winds that surround it; on the other hand, it may point to an area more concerned with practical issues than theoretical trends. While the so-called 'multilingual turn' (May, 2014) - a turn that is quite close to home - has arguably shifted applied linguistics from a narrow monolingual to a broader multilingual perspective, other turns, such as the linguistic or discursive turn (generally a poststructuralist reorientation), have still received little serious attention: "To fully appreciate the challenge represented by poststructuralism would be a revolutionary change for Applied Linguistics" (McNamara, 2015, p. 475). Other turns, whose focus may appear less relevant to the field, have had mixed effects: ecological, performative, somatic, sensory, practice and affective turns (to name a few) have been taken up in various ways but have rarely had a lasting effect. Recently, however, the spatial turn, and its allied 'trans' metaphors, has arguably started to assert a major contemporary influence. As Kramsch (2018) warns, the focus on space that has emerged in contemporary translingual metaphors and ideas such as spatial repertoires (Pennycook and Otsuji, 2014, 2015; Canagarajah, 2018) - addressing ways in which it is not only individual repertoires that matter but also the spatial affordances of place - runs the danger of omitting time, history and subjectivity from our understanding: "in any trans-perspective 
on language theories and practices, a post-structuralist focus on Space must be supplemented by a post-modern concern with Time" (Kramsch, 2018, p. 114).

Whether we see this recent emphasis on space as a poststructuralist distortion of human timespace (Schatzki, 2010), or as part of the ongoing corrective to a modernist (or postmodernist) emphasis on dynamic time over static space, the more important question here is how we understand this interest in space, arguably the disciplinary object of geography. Although it is cultural and critical geographers who were influential in inserting space into this important role across the social sciences and humanities, our engagement with spatial ideas is no more a trans- or interdisciplinary exploration of geographical concepts than it is of physics. Rather it is an attentiveness to the spatial turn put into play by geographers but taken up by many others. When we draw on other domains of work (geography, philosophy, sociology, anthropology, gender studies, cultural studies, and so on), we do so most often because these fields have also been subject to related epistemological shifts (the social, discursive, somatic, sensorial, practice, spatial and other turns).

When we borrow from other fields or disciplines, therefore, it is often precisely because those fields are drawing on related schools of thought. Theories of space, practice or ecology, for example, have been picked up in a range of applied linguistic domains, from nexus analysis (Scollon \& Scollon, 2007) to language ecologies (Kramsch, 2008; van Lier, 2000), from language practices (Kramsch, 2015; Pennycook, 2010) to communicative action (Thorne and Lantolf, 2007). Common references to cultural and critical geographers are not a result of a new-found interest in traditional domains of geography but because geography has been at the forefront of the spatial turn, and the spatial turn (like the discursive, sensory, somatic and other turns) has influenced many areas. Put another way, the issue is not one of disciplinary borrowing but of engagement with evolving epistemes as they influence different areas of study.

By talking in terms of epistemes, I am drawing in part on Foucault's (1966) notion of the episteme as systems of thought that provide the conditions of possibility for discourse, thought and action in different epochs (the Renaissance, for example). Foucault's notion of the episteme, though broader and applying to historical periods rather than scientific frameworks, is akin in some ways to Kuhn's (1970) notion of the paradigm. When we talk of paradigm shifts, we are invoking an idea not unlike an epistemic change. I take a rather less totalizing view of epistemes, however, and neither do I use the notion of episteme in relation to the more traditional philosophical distinction among common knowledge (doxa) or practice (techne). Rather, I see changing forms of knowledge and practice as intertwined in particular periods, often competing and coexisting, sometimes contradictory, sometimes not. Epistemes are framing ways of knowing that may be both common and practical. 
To develop recent work in posthumanist applied linguistics (Pennycook, 2018), for example, I drew on geography, philosophy, religion, cognitive science, biology, sociology, political science, and so on, but largely to the extent that writers in these fields were taking up questions related to posthumanism (new materialism, speculative realism, distributed cognition, sensory landscapes, spatial activism, and so on). From proclamations about the death of 'Man' to investigations into enhanced forms of being, from the advent of the Anthropocene to the new materialism and distributed cognition, the posthumanist episteme raises significant questions for applied linguistics in terms of rethinking the relation between humans and all that is deemed non-human (objects, contexts, the environment, animals, and so on). Rather than the anti-foundationalist subject of postmodernism or the discursive subject of poststructuralism, the posthumanist emphasis on new forms of materialism, embodiment and place take us towards a subject that is "materialist and vitalist, embodied and embedded" (Braidotti, 2013, p. 188). By stepping out of the humanist constructs of culture and nature, the individual and the social, and looking instead at the notion of distributed language and spatial repertoires, we can come to a new understanding of the materiality of language and social action.

The engagement with these various areas of study implies not so much a commitment to other disciplines as an exploration of an emerging posthumanist episteme. When I took up Bogost's question "What's it like to be a thing?" (2012, p. 10; Pennycook, 2018), for example, or Godfrey-Smith's (2017, p. 77) related question "What does it feel like to be an octopus?", I was not engaged in transdisciplinary work with digital media (Bogost's background) or the history and philosophy of science (Godfrey-Smith's background) but with questions of object-oriented ontologies (Bogost's interest) or the evolution of intelligent life (Godfrey-Smith's interest) as part of an exploration of the posthumanist episteme. The similarity of their questions is not coincidental: They are both posing challenges to anthropocentric claims about being and consciousness. So, to draw on spatial thinking across other fields of study is not so much a transdisciplinary as an epistemic question. And a focus on space does not take us into disciplinary fields that take a particular interest in spatial concerns but rather outward across a range of social and political domains that draw on ideas of space. This opens up possibilities for an alternative politics focused around notions such as the commons: The challenge, as Amin and Howell (2016) put it, is to reconceive the commons at a time when the most basic of commons - the planet itself - is under threat.

This rethinking of politics and space makes it possible to step away from (though not dismiss) older frameworks of political economy and instead embrace new platforms of cooperation and collective action, from solidarity networks to digital commons, from commonalities to local affiliations. This draws our attention to the constant taking over of the commons, the grabbing of water, the enclosure 
of public space, the encroachment on public life of the new technologies. Looking through the lens of the commons allows us to address modes of dispossession of common goods - from land to water, from education to healthcare - brought about by the ever more rapacious processes of neoliberal-driven capital. Seeking redress, however, is not by recourse to the failing structures of the 20th century state - rights or democracy - nor through a belief that we can step outside or overturn the tide of neoliberalism (the utopian dream of revolution or the escapist dream of avoidance). The challenge from the perspective of the commons is to focus on "spatio-temporal and ethical formations that are concerned with ways of living together that resist the privatisation and individualisation of life" (Dawney, Kirwan, and Brigstocke, 2016, pp. 12-13). The question is how to resist the new forms of enclosure (privatisation, incarceration, commodification) demanded by capital through a new focus on the commons, as space, community and possibility. Moving beyond the rally, union or ballot box to explore new modes of politics and resistance have focused on more anarchist traditions of social media-connected occupation (Occupy Movement, Indignados).

The politics of the commons takes place as a "spatial response" to processes of enclosure, a "political idiom that evokes the collective production and claiming of conceptual and physical space" (Dawney, Kirwan and Brigstocke, 2016, p. 13). Akin in a number of ways to the "place-based activism" of Larsen and Johnson (2016, p. 150), where the agency of place, "leads to a different understanding of the geographical self - to a more-than-human geographical self", these approaches to place and activism shift the grounds on which we think our politics. For a critical applied linguistic project, it is this kind of challenge that matters, one that is both political and epistemological. Rather than focusing on more traditional questions of citizenship or social justice, there is a return here to alternative anarchist roots, drawing on a range of thinkers from Mikhail Bakunin or Ivan Illich to the 'postanarchist' thought of Michel Foucault and Judith Butler (Day, 2005; Kuhn, 2009). In rethinking these politics we can therefore consider other forms of social organization and reconsider our politics, epistemologies and pedagogies "in light of the needs and desires of an anarchist society." (Armaline, 2009, p. 145)

Tying a posthumanist analysis of space, place, objects and discourse to a politics of the Commons, we can see how work on, for example, the Occupy movements can shed new light on a productive way forward for politics and applied linguistics. Such broad semiotic analyses can help us understand how the "transformation and appropriation of the space took place through the production of semiotic and linguistic resources within the occupation" (Martín Rojo, 2016, p. 6). This "occupation of urban space" she continues, is "an appropriation of a power locus, the creation of place for transgression that acquires great visibility" (2016, p. 8). Thus, by bringing different forms of analysis to the ways in which Tahrir Square 
in Cairo was transformed into a counter-space (Aboelezz, 2016), or the ways in which protest signs in Los Angeles City Hall Park are relocated though different media (Chun, 2016), we can see how multiple discourses critiquing corruption, authoritarian rule, capitalism and neoliberalism are given voice in relation to the use of public space.

A focus on space, therefore, as part of a broader attempt to connect posthumanist thought and applied linguistics, is not at the expense of time - these are concerns with the "timespace of human activity" (Schatzki, 2010, p. 1) - nor is it about bringing geographical perspectives into applied linguistics. Rather it is a question of drawing on the broad epistemic challenges that a renewed interest in space brings to the table. Posthumanist thought covers a broad range of concerns, from distributed cognition to speculative realism, from religion to animal rights, from actor network theory to object-oriented ontologies, from sensory landscapes to enhanced humans. My goals in pursuing these lines of thought were to rethink what is at stake in concerns about language in action. These broad investigations across cognition, philosophy, geography, theology, biology, sociology and anthropology are made possible precisely because applied linguistics has never convincingly been a discipline. Drawing on the new sociolinguistics, it may be more suitable to think in terms of repertoires of epistemic resources that we draw on in order to make certain ways of thinking possible.

\section{North-South knowledge hierarchies}

Applied linguistics has been narrowly constructed around particular Western or Northern frames of knowledge and language. Indeed, the attempt to ascertain the origins of applied linguistics as a discipline frequently falls into the Anglocentric trap of assuming its first use must have been in English, and to have emerged somewhere in the USA just after WWII (McCarthy, 2001). As Oda and Takada (2005) make clear, however, the term 応用言語学 (Ouyou gengo gaku) - applied linguistics (as elsewhere used particularly in relation to ELT) - was in use in the 1930s in Japan. And if only we looked, there would probably be many other such instances. It is not only orthodox applied linguistics that may be guilty of such blindness. With the dominance of Northern academic work and particularly of work published in English, it appears at times as if critical traditions emerged only in particular Northern contexts (critical discourse analysis in the UK and critical pedagogy in the US in the late 1970s or early 1980s, for example) and only in a timeframe that marks the translation of influential texts into English, as the work of Foucault, Bakhtin, Vološinov, Fanon, Freire and others invigorated the limited traditions of monolingual Anglophone worlds. 
But social and political activism and its critical academic counterparts have been alive and well in other languages and other parts of the world alongside their incorporation into the central Anglophone institutions. Paulo Freire's work is a good example. Not only did his literacy work in Recife in the 1960s very obviously predate its influence in North America (which is generally seen to start with the 1970 publication of the translated Pedagogy of the Oppressed), but it also developed in dialogue with other traditions (the work of César, Fanon and others from the French Caribbean, for example), and has continued as an educational and literacy movement both in Brazil and in other places influenced by this work (literacy movements from Cuba to Timor Leste) (Broughton, 2017), operating both independently and in dialogue with its English-language offsprings.

To talk of transdisciplinarity in such contexts is to emphasize relations between or across comfortable disciplines of the North when what we actually need to do is both to undermine such hegemonic knowledge structures and to seek a much better understanding of alternative frameworks of knowledge. Applied linguistics in recent years has become a somewhat moribund area of work, with internal squabbles over models of language development, and interminable debates about the relation between linguistics and applied linguistics, or what constitutes applied linguistics. This tired domain may be reinvigorated through southern insights. An applied linguistics that can embrace Global South perspectives needs researchers who are culturally grounded, political engaged, continuously self-reflexive, and capable of adopting multiple perspectives on data. Part of the agenda here is to widen sociolinguists' and applied linguists' "epistemological repertoire" (di Carlo, 2018, p. 139) so that research methods, interpretive tools and interventionist and applied projects are far better attuned to social and cultural contexts that are outside the mainstream experiences of applied linguistics.

Levon's (2017, p. 280) review of Coupland's (2016) edited book on sociolinguistic debates points to "the geopolitical positioning of the various contributions" being almost exclusively in the North: The effects of the overwhelming majority of contributors being located in the global North (and primarily in North America and Western Europe), he suggests, are twofold: on the one hand "it makes it seem as if sociolinguistics does not take place outside of North America and Western Europe, whereas this is clearly not the case". It is unfortunate and limiting that sociolinguists from elsewhere - Africa, South America, or South and East Asia are not included. On the other hand, this absence perpetuates "a particular geopolitics of knowledge that privileges Northern perspectives and prevents Southern scholars from contributing a differently positioned interpretation of events and practices that concern them..." (Levon, 2017, pp. 280-281). This critique thus points to two kinds of omission: First, scholars from outside Europe and North America are not included, which means generally that these contexts of research 
are also not included; and second, alternative epistemologies that might derive from these southern contexts (southern epistemologies; Santos, 2018) are not as a result given any space.

There remains in applied linguistics a deplorable blindness towards contexts and ideas outside the Global North. Talk of transdisciplinary applied linguistics avoids the need for engagement by focusing on academic disciplines rather than the broader politics of knowledge. In book after book, conference after conference, article after article, academics from a narrow range of contexts - mainly European and North American, but also members of that postcolonial elite that work elsewhere - discuss research on specific contexts and generalise these to the wider world. Under claims of commonality - humanity, language, disciplinarity classed, raced, and locality-based understandings of language use are assumed to be applicable to the majority world elsewhere. While the ways in which these differences are framed - the majority world, the Global North and South, the West and the Rest, First and Third worlds, developed and developing societies - and the concerns that are highlighted within these frameworks - economic, political, social, epistemological and other disparities - remain points of continuing discussion and dispute, it is nevertheless clear that an inequitable knowledge hierarchy ensures that certain assumptions about language, diversity and education are given precedence over other possibilities elsewhere.

When the northern gaze does fall on its southern neighbours, such assumptions continue in ways of thinking about multilingualism, mother tongue education, language preservation, research and so on (Makoni and Pennycook, 2017). It is often assumed that southern multilingualism must be about language endangerment or diversity. This is more about the northern rush to worry about saving languages for the good of humanity or to marvel at the complexity of language resources in southern contexts than an engagement with southern matters of concern (Mufwene, 2016). To assume that the South is diverse or that languages are endangered is to continue to gaze from northern perspectives. This is not to say that many southern contexts are not places of great diversity, nor that many languages may cease to be used. Rather it is to challenge the assumptions both that such concerns are essentially what matter in the South and that the notions of diversity or endangerment make sense in such contexts (Khubchandani, 1997). We need to raise more important questions than mother tongue education or language endangerment, not so much because they do not matter, but rather because they are ill-framed.

Part of this critique of the dominance of Global North perspectives also addresses the need to seek ideas outside disciplinary confines, making a case for a greater role for local forms of knowledge about languages, their use, their social and cultural roles, or their place in education. As Dasgupta (1997, p. 24) notes, 
"the specialists in individual disciplines insist on thinking just once, and on ensuring only internal accountability." For de Souza (2017, p. 206) the problem is that "the posture of some mainstream social scientists who claim to be pro-indigenous, and in favour of the preservation of indigenous languages and epistemologies" remains all too often "trapped within the bounds of their own Enlightenment epistemologies." When these researchers "claim to listen to the indigenous other, they apparently only hear their own voices and values" unable to escape from the "bounds of lazy thinking, and thus liable to waste the wealth of experience of the ecology of knowledges that surrounds them but remains invisible to their eyes".

De Souza (2017) is here taking up Santos' (2012) notion of 'lazy reason' (razão indolente) - the critique that dominant modes of thinking cannot understand or engage with alternative modes of thought. This "lingering inheritance of coloniality and its unequal distribution of knowledges, bodies, and languages" persists and may be something that applied linguistics, in its focus on education, needs to be aware of in order to "avoid, albeit unwittingly, continuing the legacy of coloniality." (de Souza, 2017, p. 206). Dasgupta (1997) goes on to argue that linguists actually need to take seriously the responsibility of "thinking twice and of representing the public interest in the realm of thinking" in order to avoid the narrowness of a disciplinary focus that is only engaged in discussion with itself (p. 24). In the context of applied linguistics from the South, this means opening up to and learning to listen to a much wider domain or people who can not only act as 'linguistic informants' and 'research subjects' but who can also become part of knowledge building.

Some may be sceptical about challenges to the "private arrogances" (Dasgupta, 1997, p. 24) of disciplines since the whole point of developing a discipline, a set of theories, an academic domain, a body of knowledge and research methods is precisely to overcome ordinary people's ideas about things. People have all sorts of prejudiced, misguided or simply ill-informed ideas about language, and the point of applied linguistics is to present a much more careful account of what is going on. The point here, however, is by no means to dismiss all forms of applied linguistic research and argument on the benefits, for example, of bilingualism (though with careful caveats about static and reductive notions of bilingualism; Otsuji and Pennycook, 2018), or mother tongue education (though with reservations about what constitutes a mother tongue and its pedagogical role; Makoni and Pennycook, 2012), but rather to appreciate that the assumptions behind such arguments have to be understood as articulated from within a particular set of understandings of language and ideological views of society. Orthodox applied linguistics takes a view of language as a given and thus assumes that it is dealing with "determinate rule-based systems called languages" (Harris, 1990, p. 49), rather than asking the more useful question as to how our beliefs about language derive from communicational processes. 
The challenge, as de Korne and Leonard (2017, p. 7) remark, is how to avoid these "narrow perspectives on language use and knowledge that are potentially harmful to speech communities" and how to support the "promotion of minoritised languages by ground-level participants [as] fundamentally a political act through which participants negotiate control over linguistic authority, knowledge production, and self-definition through their linguistic practices." While expertise may be really useful, we should also be very sceptical about some of the unexamined premises on which such expertise is based and guard against it becoming tyrannical, colonizing our visions of language. Albury's (2016, p. 306) study of folk linguistic attitudes to te reo Māori in Aotearoa/ New Zealand points to the problem of "universal language revitalisation theories that draw on Western European perspectives on language but assume universal relevance," and shows instead how many assumptions about standardisation, literacy and corpus planning are questioned from Māori perspectives. From this point of view "folk linguistic research methods can contribute to the decolonization of sociolinguistic theory and method by understanding, voicing, legitimising, and ultimately applying more ontologies and epistemologies of language than those that generally premise current scholarship" (Albury, 2017, p. 37)

The concern here is that since much applied linguistic work - whether 'critical' or otherwise - is based on Global North contexts and theories, it is simply not readily usable in the Global South. As Makoni (2003) has argued, not only mainstream applied linguistics but also critical applied linguistics lacks adequately contextualized strategies for engaging with local communities. Remaining aware of the diverse contexts in which it may hope to be applicable, applied linguistics needs to be cautious lest the very terms and concepts of any critical project at the same time inflict damage on the communities with which critical applied linguists wish to work. The challenge here is to ensure that "the research agenda is formulated in collaboration and consultation with local communities" (Makoni, 2003, p. 135) in order not only to develop a relationship between critical scholarship and local knowledge and practice but also to encourage the development of (critical) applied linguistics as localized practice (Couzens \& Eira, 2014). Ndhlovu (2017, p. 92) argues for the importance of "the burgeoning scholarship from the Global South (Asia, Africa and Latin America) in calling for pluralisation of toolkits" to understand questions of language and culture in the Global South.

Applied linguistics from a southern perspective seeks not so much to add further details to the disciplinary archive but rather to develop an applied linguistic anarchive by addressing the darker side of applied linguistics (cf. Mignolo, 2011): the deep ties of the colonial and neo-colonial projects to language teaching; the exoticization of differences that reinforces the construction of racialized and ethnicised Others; and the normative assumptions about gendered and sexual relations that 
obscure the politics of sexuality. In order to redress these deep-seated concerns, we need not merely to encourage a more inclusive applied linguistics that opens the doors to southern voices and encourages more research on southern contexts; we need to open up to a much wider range of ways of thinking. The challenge, therefore, is about more than an agenda of southern inclusion but rather about expanding epistemological repertoires, of opening up to the obligation to understand that inquiries into applied linguistic concerns elsewhere in the world must also be inquiries into other ways of thinking that offer possibilities of disciplinary renewal.

\section{Conclusion: Refreshing epistemological repertoires}

If we wish to engage with notions of transdisciplinarity, it is also time to acknowledge that applied linguistics has never been a convincing discipline - despite some hard work in some quarters to construct the necessary trenches and barriers - and is all the better for that. Disciplines, like standard languages, have always been exclusionary: on the good side they help consolidate ideas, enhance collaboration, bring solidity to a field; on the downside they narrow the area of interest, its ideas and methods, and they exclude so much that does not fit. Disciplines are hegemonic knowledge structures. While bringing the possible benefits of fixity, assurity, annual conferences and manageable course reading lists, they constrain the possibilities of intellectual work. Critical work should always oppose disciplinarity. Research framed only by a critical politics and a static disciplinary epistemology fails to acknowledge the need to rethink the grounds on which we operate. Critical applied linguistics needs much more than the mere addition of a critical politics to normative applied linguistics; it also needs a much more transgressive side (Pennycook, 2006).

Applied linguistics operates as a constellation of shifting interests around language in the world and is particularly unsuited to disciplinary confines. If, as Halliday (2001) suggests, a transdisciplinary focus necessarily moves beyond disciplinary boundaries, creating new themes or activities, the focus here is not on applied linguistics as a transdisciplinary field but on language-oriented activities that draw on different domains. To talk, then, of transdisciplinarity in applied linguistics is in some ways to describe things as they have always been, but the notion obscures several more important concerns. There are two useful parallels to be drawn from the new sociolinguistic focus on translinguistic practices (Li Wei, 2018). On the one hand, the translinguistic supersedes the linguistic, challenging underlying assumptions about the ontological status of languages. Translanguaging is not just a new term for mixing languages together but a different way of thinking 
about what languages are. Likewise, a move towards transdisciplinary thinking challenges disciplinary assumptions, and renders the already questionable disciplinary status of applied linguistics even less sustainable.

The translinguistic focus on repertoires of semiotic resources, on the other hand, suggests a way of thinking about applied linguistic theory in terms of epistemological resources that we draw on in order to engage in certain languagerelated concerns. Transdisciplinarity is not the solution to overcoming disciplinary straightjacketing, not only because it has clearly been co-opted by various academic regimes (funding bodies and other institutions that now almost require us to make inter- or transdisciplinary genuflections) or because the idea has rarely offered more than a superficial sense of plurality, but also because engagement across domains is more often an engagement across epistemes, and because the real questions applied linguistics needs to face are those of its applicability and responsibility to a wider set of contexts and ideas than has been the case up to now. Rather than thinking of applied linguistics as a transdisciplinary endeavour, therefore, it is more useful to think in terms of an epistemic assemblage.

The recent focuses on assemblages opens up a more practical way for us to think about what applied linguistics is. There is currently a broad move afoot to reconfigure what counts as language and how social, spatial and material worlds interact. Hence conjunctural analysis (Varis, 2017), entanglements (Toohey et al. 2015; Kerfoot \& Hyltenstam, 2017) or assemblages (Canagarajah, 2018; Pennycook, 2017; Pennycook \& Otsuji, 2017) have been taken up to account for the interrelationships among multiple forms of semiosis. The notion of assemblages as "ad hoc groupings of diverse elements, of vibrant materials of all sorts" (Bennett, 2010, p. 23) allows for an understanding of how different trajectories of people, semiotic resources and objects meet at particular moments and places. This opens up alternative ways of thinking that focuses not so much on language use in particular contexts - as if languages preexist their instantiation in particular places, having been carried around by people as mobile language containers - but rather on the ways in which particular assemblages of objects, linguistic resources and places come together.

By analogy, we might start to think in terms of applied linguistics less in disciplinary or transdisciplinary terms and more as temporary assemblages of thought and action that come together at particular moments when language-related concerns need to be addressed. This flexible account of applied linguistic practice takes us not only beyond concerns about its disciplinary status but also beyond the idea of a transdisciplinary applied linguistics. It also helps us see how applied linguistic practices, which may appear diverse, confused or undisciplined, are instead the coming together of different language-oriented projects, epistemes and matters of concern. Such an understanding makes it possible to see how work that apparently 
draws on other disciplines is really engaged in emerging epistemes that cut across areas of the social sciences and humanities. It opens up applied linguistics to an ethical engagement with alternative ways of thinking about language and context from the Global South, so that renewal of applied linguistics comes not via other disciplines but rather through alternative forms of knowledge.

\section{References}

Aboelezz, M. (2016). The geosemiotics of Tahrir Square: A study of the relationship between discourse and place. In L. Martín Rojo (Ed.), Occupy: The spatial dynamics of discourse in global protest movements (pp. 23-46). Amsterdam: John Benjamins.

Albury, N. J. (2016). Defining Māori language revitalisation: A project in folk linguistics. Journal of Sociolinguistics, 20, 287-311. https://doi.org/10.1111/josl.12183

Albury, N. J. (2017). How folk linguistic methods can support critical sociolinguistics. Lingua, 199, 36-49. https://doi.org/10.1016/j.lingua.2017.07.008

Amin, A. \& Howell, P. (2016). Thinking the commons. In A. Amin \& P. Howell (Eds.), Releasing the commons: rethinking the futures of the commons (pp. 1-17). London: Routledge.

Armaline, W. (2009). Thoughts on anarchist pedagogy and epistemology. In R. Amster, A. DeLeon, L. Fernandez, A. Nocella II, \& D. Shannon (Eds.), Contemporary anarchist studies: An introductory anthology of anarchy in the academy (pp. 136-146). New York: Routledge.

Becher, T. (1989). Academic Tribes and Territories: Intellectual enquiry and the culture of disciplines. Buckingham: Open University Press.

Bennett, J. (2010). Vibrant matter: A political ecology of things. Durham: Duke University Press.

Bernstein, B. (2000). Pedagogy, Symbolic Control and Identity, 2nd Edition. Oxford: Rowman \& Littlefield Publishers.

Bogost, I. (2012). Alien phenomenology, or what it's like to be a thing. Minneapolis: University of Minnesota Press. https://doi.org/10.5749/minnesota/9780816678976.001.0001

Braidotti, R. (2013). The posthuman. Cambridge: Polity.

Broughton, B. (2017). Popular education and mass literacy campaigns. Beyond 'New Literacy Studies'. In K. Yasukawa \& S. Black (Eds.), Beyond economic interests: Critical perspectives on adult literacy and numeracy in a globalised world (pp. 149-164). Rotterdam: Sense Publishers.

Canagarajah, A. S. (2018). Translingual practice as spatial repertoires: Expanding the paradigm beyond structuralist orientations. Applied Linguistics, 39(1), 31-54. https://doi.org/10.1093/applin/amx041

Chun, C. (2016). Mobilities of a linguistic landscape at Los Angeles City Hall Park. In L. Martín Rojo (Ed.), Occupy: The spatial dynamics of discourse in global protest movements (pp. 77-98). Amsterdam: John Benjamins

Coupland, N. (Ed.) (2016). Sociolinguistics: Theoretical debates. Cambridge: Cambridge University Press. https://doi.org/10.1017/CBO9781107449787

Couzens, V. \& Eira, C. (2014). Meeting point: Parameters for the study of revival languages. In P. Austin \& J. Sallabank (Eds.), Endangered languages: Beliefs and ideologies in language documentation and revitalisation (pp. 313-333). Oxford: Oxford University Press. https://doi.org/10.5871/bacad/9780197265765.003.0015 
Dasgupta, P. (1997). Foreword. In L. Khubchandani Revisioning Boundaries: A plurilingual ethos (pp. 11-29). New Delhi: Sage.

Davies, A. (1999). An introduction to applied linguistics: From theory to practice. Edinburgh: Edinburgh University Press.

Davies, A. (2005). A glossary of applied linguistics. Edinburgh: Edinburgh University Press.

Dawney, L., S. Kirwan, Brigstocke, S. \& J. (2016). Introduction: The promise of the commons. In J. Brigstocke, L. Dawney, \& S. Kirwan (Eds.), Space, Power and the Commons: The Struggle for Alternative Futures (pp. 12-31). London: Routledge.

Day, R. (2005). Gramsci Is Dead: Anarchist currents in the newest social movements, London: Pluto Press.

De Bot, K. (2015). A history of applied linguistics: From 1980 to the present. New York: Routledge.

De Korne, H., \& Leonard, W. (2017). Reclaiming languages: Contesting and decolonising 'language endangerment' from the ground up. In W. Y. Leonard \& H. D. Korne (Eds.), Language Documentation and Description (Vol. 14, pp. 5-14). London: EL Publishing.

De Souza, L. M. (2017). Epistemic diversity, lazy reason, and ethical translation in postcolonial contexts. The case of Indigenous educational policy in Brazil. In C. Kerfoot \& K. Hyltenstam (Eds.), Entangled discourses: South-north orders of visibility (pp. 189-208). New York: Routledge.

Di Carlo, P. (2018). Towards an understanding of African endogenous multilingualism: Ethnography, language ideologies, and the supernatural. International Journal of Sociology of Language, 254, pp. 139-163.

Foucault, M. (1966). Les mots et les choses: Une archéologie des sciences humaines. Paris: Éditions Gallimard.

García, O. \& Li Wei. (2014). Translanguaging: Language, Bilingualism and Education. Basingstoke: Palgrave Macmillan. https://doi.org/10.1057/9781137385765

Godfrey-Smith, P. (2017). Other minds: The octopus and the evolution of intelligent life. London: William Collins.

Halliday, M. A. K. (2001). New ways of meaning. The challenge to applied linguistics. In Fill, A. \& Mühlhäusler, P. (Eds.), The Ecolinguistics Reader. Language, ecology and environment (pp. 175-202). London: Continuum.

Harris, R. (1990). On redefining linguistics. In H. Davis \& T. Taylor (Eds.), Redefining linguistics (pp. 18-52). London: Routledge.

Kaplan, R. (2002). Preface. In R. Kaplan (Ed.), The Oxford handbook of applied linguistics. Oxford: Oxford University Press.

Kerfoot, C. \& Hyltenstam, K. (2017). Introduction: Entanglement and orders of visibility. In C. Kerfoot \& K. Hyltenstam (Eds.). Entangled Discourses: South-North Orders of Visibility (pp. 1-15). New York: Routledge.

Khubchandani, L. (1997). Revisioning Boundaries: A plurilingual ethos. New Delhi: Sage.

Kramsch, C. (2008). Ecological perspectives on foreign language education. Language Teaching, 41, 389-408. https://doi.org/10.1017/So261444808005065

Kramsch, C. (2015). Applied linguistics: A theory of the practice. Applied Linguistics, 36(4), 454-465. https://doi.org/10.1093/applin/amv039

Kramsch, C. (2018). Trans-spatial utopias. Applied Linguistics, 39(1), 108-115. https://doi.org/10.1093/applin/amx057

Kuhn, G. (2009). Anarchism, postmodernity, and poststructuralism. In R. Amster, A. DeLeon, L. Fernandez, A. Nocella II, \& D. Shannon (Eds.), Contemporary anarchist studies: An introductory anthology of anarchy in the academy (pp. 18-25). New York: Routledge. 
Kuhn, T. (1970). The structure of scientific revolutions. (2nd edition). Chicago: University of Chicago Press.

Larsen, S. \& Johnson, J. (2016). The agency of place: Toward a more-than-human geographical self. GeoHumanities, 2(1), 149-166. https://doi.org/10.1080/2373566X.2016.1157003

Latour, B. (2004). Why has critique run out of steam? From matters of fact to matters of concern. Critical Inquiry, 30(2), 225-248. https://doi.org/10.1086/421123

Levon, E. (2017). Situating sociolinguistics: Coupland - Theoretical Debates. Journal of Sociolinguistics, 21(2), 272-288. https://doi.org/10.1111/josl.12233

Li, Wei. (2018). Translanguaging as a practical theory of language. Applied Linguistics, 39(1), 9-30. https://doi.org/10.1093/applin/amx039

Lyotard, J.-F. (1984). The postmodern condition: A report on knowledge. Minneapolis: University of Minnesota Press.

Makoni, S. (2003). Review of A. Davies, An introduction to applied linguistics: From practice to theory and A. Pennycook, Critical applied linguistics: A critical introduction. Applied Linguistics, 24(1), 130-137.

Makoni, S. \& Pennycook, A. (2007). Disinventing and reconstituting languages, in S. Makoni \& A. Pennycook (Eds.), Disinventing and reconstituting languages (pp. 1-41). Clevedon: Multilingual Matters.

Makoni, S. \& Pennycook, A. (2012). Disinventing multilingualism: from monological multilingualism to multilingua francas. In M. Martin-Jones, A. Blackledge \& A. Creese (Eds.), The Routledge Handbook of Multilingualism (pp. 439-453). Routledge: New York.

Martín Rojo, L. (2016). Occupy: The spatial dynamics of discourse in global protest movements. In L. Martín Rojo (Ed.), Occupy: The spatial dynamics of discourse in global protest movements (pp. 1-22). Amsterdam: John Benjamins.

May, S. (2014). Disciplinary divides, knowledge construction, and the multilingual turn. In S. May (Ed.), The multilingual turn: Implications for SLA, TESOL and bilingual education (pp. 7-31). London: Routledge.

McCarthy, M. (2001). Issues in applied linguistics. Cambridge: Cambridge University Press.

McNamara, T. (2015). Applied linguistics: The challenge of theory. Applied Linguistics. 36(4): 466-477. https://doi.org/10.1093/applin/amvo42

Mignolo, W. (2011). The Darker Side of Western Modernity: Global Futures, Decolonial Options. Durham: Duke University Press. https://doi.org/10.1215/9780822394501

Mufwene, S. (2016). A cost-and-benefit approach to language loss. In L. Filipović \& M. Pütz (Eds.), Endangered Languages and Languages in Danger: Issues of documentation, policy, and language rights (pp. 115-143). Amsterdam: John Benjamins. https://doi.org/10.1075/impact.42.06muf

Ndhlovu, F. (2017). Southern development discourse for Southern Africa: Linguistic and cultural imperatives. Journal of Multicultural Discourses 12(2): 89-109.

https://doi.org/10.1080/17447143.2016.1277733

Oda, M. \& Takada, T. (2005). English Language Teaching in Japan. In G. Braine (Ed.), Teaching English to the World: History, Curriculum and Practice (pp. 93-101). New York: Lawrence Erlbaum Associates.

Otsuji, E. \& Pennycook, A. (2018). The translingual advantage: Metrolingual student repertoires, in Choi, J. \& Ollerhead, S. (Eds.), Plurilingualism in teaching and learning: Complexities across contexts (pp. 71-88). New York: Routledge.

Pennycook, A. (2001). Critical applied linguistics: A critical introduction. Mahwah, NJ: Lawrence Erlbaum. 
Pennycook, A. (2006). Uma lingüîstica aplicada transgressiva. In L. P. Moita Lopes (Org.) Por uma lingüîstica aplicada indisciplinar (pp. 67-84). Sao Paulo: Parabola.

Pennycook, A. (2007). Global Englishes and transcultural flows. London: Routledge.

Pennycook, A. (2010). Language as a local practice. London: Routledge. https://doi.org/10.4324/9780203846223

Pennycook, A. (2017). Translanguaging and semiotic assemblages. International Journal of Multilingualism, 14(3), 269-282. https://doi.org/10.1080/14790718.2017.1315810

Pennycook, A. (2018). Posthumanist applied linguistics. London: Routledge.

Pennycook, A., \& Otsuji, E. (2014). Metrolingual multitasking and spatial repertoires: 'Pizza mo two minutes coming. Journal of Sociolinguistics, 18(2), 161-184.

https://doi.org/10.1111/josl.12079

Pennycook, A. \& Otsuji, E. (2015). Metrolingualism: Language in the city. London: Routledge.

Pennycook, A. \& Otsuji, E. (2017). Fish, phone cards and semiotic assemblages in two Bangladeshi shops in Sydney and Tokyo. Social Semiotics, 27(4), 434-450. https://doi.org/10.1080/10350330.2017.1334391

Rampton, B. (1997). Retuning in applied linguistics. International Journal of Applied Linguistics, 7, 3-25. https://doi.org/10.1111/j.1473-4192.1997.tboo101.x

Santos, B. d. S. (2012). Public sphere and epistemologies of the south. Africa Development, 37(1), 43-67.

Santos, B. d. S. (2018). The end of the cognitive empire: The coming of age of epistemologies of the south. Durham, NC: Duke University Press.

Schatzki, T. (2010). The timespace of human activity: On performance, society, and history as indeterminate teleological events. Lanham: Lexington Books.

Scollon, R. \& Scollon, S. W. (2007). Nexus analysis: Refocusing ethnography on action. Journal of Sociolinguistics, 11(5), 608-625. https://doi.org/10.1111/j.1467-9841.2007.00342.x

Thorne, S., \& Lantolf, J. (2007). A linguistics of communicative activity. In S. Makoni \& A. Pennycook (Eds.), Disinventing and reconstituting languages (pp. 170-195). Clevedon: Multilingual Matters.

Thurlow, C. (2016). Queering critical discourse studies or/and performing 'post-class' ideologies. Critical Discourse Studies, 13(5), 485-514. https://doi.org/10.1080/17405904.2015.1122646

Toohey, K., Dagenais, D., Fodor, A., Hof, L., Nuñez, O., \& Singh, A. (2015). 'That sounds so cooool': Entanglements of children, digital tools, and literacy practices. TESOL Quarterly, 49(3), 461-485. https://doi.org/10.1002/tesq.236

Trowler, P. (2014). Depicting and Researching Disciplines: Strong and moderate essentialist approaches. Studies in Higher Education, 39 (10), 1720-1731. https://doi.org/10.1080/03075079.2013.801431

Trowler, P., Saunders, M. \& Bamber, V. (Eds.). (2012). Tribes and territories in the 21st-century. Rethinking the significance of disciplines in higher education. London: Routledge.

Varis, P. (2017). Superdiverse times and places: Media, mobility, conjunctures and structures of feeling. In K. Arnaut, M. Sif Karrebaek, M. Spotti, \& J. Blommaert (Eds.). Engaging superdiversity: Recombining spaces, times and language practices (pp. 25-46). Bristol: Multilingual Matters.

van Leeuwen, T. (2018). Moral evaluation in critical discourse analysis. Critical Discourse Studies. https://doi.org/10.1080/17405904.2018.1427120 
Van Lier, L. (2000). From input to affordance: Social-interactive learning from an ecological perspective. In J. Lantolf (Ed.), Sociocultural Theory and Second Language Learning (pp. 155-177). Oxford: Oxford University Press.

Widdowson, H. G. (2001). Coming to terms with reality: Applied linguistics in perspective. In D. Graddol (Ed.). Applied Linguistics for the 21st Century, AILA Review, 14, 2-17. 